\title{
Bromine monoxide/sulphur dioxide ratios in relation to volcanological observations at Mt. Etna 2006-2009
}

\author{
N. Bobrowski ${ }^{1}$ and G. Giuffrida ${ }^{2}$ \\ ${ }^{1}$ Institute for Environmental Physics, Heidelberg, Germany \\ ${ }^{2}$ Istituto Nazionale di Geofisica e Vulcanologia, Palermo, Italy \\ Correspondence to: N. Bobrowski (nicole.bobrowski@iup.uni-heidelberg.de) \\ Received: 6 March 2012 - Published in Solid Earth Discuss.: 16 March 2012 \\ Revised: 28 August 2012 - Accepted: 10 October 2012 - Published: 4 December 2012
}

\begin{abstract}
Over a 3-yr period, from 2006 to 2009, frequent scattered sunlight DOAS measurements were conducted at Mt. Etna at a distance of around $6 \mathrm{~km}$ downwind from the summit craters. During the same period and in addition to these measurements, volcanic observations were made by regularly visiting various parts of Mt. Etna.

Here, results from these measurements and observations are presented and their relation is discussed. The focus of the investigation is the bromine monoxide/sulphur dioxide $\left(\mathrm{BrO} / \mathrm{SO}_{2}\right)$ ratio, and its variability in relation to volcanic processes.

That the halogen/sulphur ratio can serve as a precursor or indicator for the onset of eruptive activity was already proposed by earlier works (e.g. Noguchi and Kamiya 1963; Menyailov, 1975; Pennisi and Cloarec, 1998; Aiuppa et al., 2002). However, there is still a limited understanding today because of the complexity with which halogens are released, depending on magma composition and degassing conditions. Our understanding of these processes is far from complete, for example of the rate and mechanism of bubble nucleation, growth and ascent in silicate melts (Carroll and Holloway, 1994), the halogen vapour-melt partitioning and the volatile diffusivity in the melt (Aiuppa et al., 2009).

With this study we aim to add one more piece to the puzzle of what halogen/sulphur ratios might tell about volcanic activities. Our data set shows an increase of the $\mathrm{BrO} / \mathrm{SO}_{2}$ ratio several weeks prior to an eruption, followed by a decline before and during the initial phase of eruptive activities. Towards the end of activity or shortly thereafter, the ratio increases to baseline values again and remains more or less constant during quiet phases. To explain the observed evolution of the $\mathrm{BrO} / \mathrm{SO}_{2}$ ratio, a first empirical model is pro-
\end{abstract}

posed. This model suggests that bromine, unlike chlorine and fluorine, is less soluble in the magmatic melt than sulphur.

By using the DOAS method to determine $\mathrm{SO}_{2}$, we actually observe most of the emitted sulphur of Mt. Etna. Regarding bromine, however, we are aware that by determining only the bromine monoxide $(\mathrm{BrO})$ radical we might just observe a small or even a variable fraction of the total emitted bromine, which is most probable originally in the form of $\mathrm{HBr}$. Therefore, we present first studies to justify the assumption that, despite the disadvantage just mentioned, the $\mathrm{BrO} / \mathrm{SO}_{2}$ ratio can nevertheless serve as a new parameter to indicate the state of a volcano, when measurements are conducted under certain, but rather convenient, conditions.

\section{Introduction}

Etna is a significantly and continuously degassing volcano with frequently occurring eruptive activity. It is situated on the eastern side of Sicily and has four active summit craters. Being a rather developed tourist destination in Europe, there are less logistical challenges than at most other volcanic sites. Therefore, Mt. Etna is a perfect place to study variations in the chemical composition of volcanic plume during volcanic phenomena.

Halogen / sulphur ratios, in particular chlorine / sulphur ratios, in volcanic plumes are considered to be geochemical tools for monitoring volcanic activity (e.g. Tazieff and Sabroux, 1983). Most of the studies have been carried out for chlorine, less for fluorine and nearly none for bromine and iodine. The probably main reason for this is the limited sensitivity for the detection of the much less abundant 
heavier halogens. Most investigations showed decreasing chlorine/sulphur $(\mathrm{Cl} / \mathrm{S})$ ratios prior to or during volcanic activity (e.g. Noguchi and Kamiya, 1963; Stoiber and Rose, 1970; Menyailov, 1975; Pennisi and Chloarec, 1998; Aiuppa et al., 2002). Nevertheless, careful interpretations and differentiated discussions on the data in context of the volcanic environment are necessary like e.g. discussed in Edmonds et al. (2001). Edmonds et al. (2001) showed that the $\mathrm{HCl}$ flux could be used as a proxy for the extrusion rate, whilst the variations in the $\mathrm{SO}_{2}$ emissions were closely related to changes in the soil permeability. Edmonds et al. (2001) showed that, in the case of Soufrière Hills volcano, Montserrat, this information can be used to find conclusions about the state of the eruption. The eruptive events were finishing there when $\mathrm{SO}_{2}$ emissions remained consistently low, $\mathrm{HCl}$ emission rates were less than $100 \mathrm{td}^{-1}$ and the $\mathrm{HCl} / \mathrm{SO}_{2} \mathrm{ra}-$ tio was less than 0.1 .

In early studies, $\mathrm{Cl} / \mathrm{S}$ ratios were collected only by dangerous sampling directly from the emission source. More recently, remote sensing techniques, in particular Fourier transform infrared spectroscopy (FTIR), are applied as well (e.g. Francis et al., 1998, Edmonds et al., 2001, Horrocks et al., 2003; Burton et al., 2007, 2010; Oppenheimer et al., 2008). This new possibility due to the improvements of measurement technology allows studies with a higher time resolution (e.g. Caltabiano et al., 2004; Burton et al., 2003) and therefore provides a better understanding, especially of rapid processes like explosions (e.g. Burton et al., 2007; Edmonds et al., 2009). Unfortunately, this method is often applied in a safe distance only during clear sky conditions, because usually direct sunlight is used as light source. Other infrared radiation sources can be applied, e.g. hot lava bodies or infrared lamps, commonly used only for the case of crater rim measurements or active eruptive sites, but in those cases the measurements are carried out in a close distance (hundreds of meters) to the active volcanic source.

Furthermore, recent laboratory and model studies of vapour-melt partition coefficients and diffusion properties of sulphur and chlorine (e.g. Villemant and Boudon, 1999; Bureau et al., 2000; Moretti et al. 2003; Aiuppa et al., 2004; Spilleart et al., 2006; Aletti et al., 2007) contributed to an improved understanding of volcanic processes as well (e.g. Aiuppa et al., 2004; Spilliaert et al., 2006; Burton et al., 2007). However, it has to be mentioned that many questions remain still open (e.g. Aiuppa, 2009; Shinohara, 2009) and disagreements of the chlorine partitioning in comparison to sulphur between some of the studies prove the incomplete understanding of the process (see Aiuppa et al., 2004 figures 5 and 6 in comparison to Spilliaert et al., 2006 figure 4).

Beside chlorine, as mentioned above, fluorine, bromine and iodine are also emitted from volcanoes (e.g. Aiuppa et al., 2005), but much less research has been undertaken on these halogens until now. Most halogens are predicted (thermodynamically) to escape from magma as halogen halides (HCl, $\mathrm{HBr}$ etc, e.g. Gerlach, 2004) and in small parts as halo- gen molecules or even in the form of atoms. However, more recent studies of von Glasow (2010) propose that $\mathrm{HBr}$ at the crater rim would only have a proportion of $60 \%$ of the total emitted bromine and decrease rapidly in an ageing plume down to below $20 \%$ after roughly $10 \mathrm{~min}$; instead $\mathrm{BrO}$ would have a fraction of total bromine emissions of about $10 \%$ in any case and does not even change dramatically in the ageing plume after the first few minutes (e.g. Bobrowski et al., 2009; Vogel et al., 2010).

In this study we explore the possibility of using $\mathrm{BrO} / \mathrm{SO}_{2}$ measurements as a further parameter to enhance our knowledge of gas emission changes as indicators of magma movements. $\mathrm{BrO}$ and $\mathrm{SO}_{2}$ are both readily measurable with UV spectrometers under conditions less limited to weather than measurements of $\mathrm{HCl}$ and $\mathrm{HF}$ with the FTIR technique at safe distances from the emission source. Therefore, $\mathrm{BrO} / \mathrm{SO}_{2}$ ratios could provide a convenient and continuous additional measurement parameter.

$\mathrm{BrO}$ is not thought to exist as a significant bromine species in the magmatic gas, and it is predicted to be formed once the plume comes into contact with the surrounding atmosphere. In fact, $\mathrm{BrO}$ mixing ratios are predicted to increase rapidly (by photolysis) in the presence of sunlight (e.g. Oppenheimer et al., 2006; Bobrowski et al., 2007; von Glasow, 2010), due to the autocatalytic bromine explosion mechanism (Wennberg, 1999). In light of this disadvantage, first sensitivity studies are presented of the behaviour of $\mathrm{BrO}$ under various meteorological conditions and plume ages.

The presented 3-yr time series, during which two eruptions have taken place, will demonstrate that $\mathrm{BrO} / \mathrm{SO}_{2}$ ratios might become a proper tracer of volcanic activity in the future.

\section{Measurements}

Differential optical absorption spectroscopy (DOAS) is an analysis technique first used by Perner et al. (1976), and it is usually applied to analyse UV-VIS spectra with spectral resolution below $1 \mathrm{~nm}$. The multi-axis UV-spectrometer used in this work will be called in the following MAX-DOAS. Beside MAX-DOAS measurements between 2006-2009, also 2004 and $2005 \mathrm{BrO} / \mathrm{SO}_{2}$ measurements were carried out using a Max-DOAS instrument approximately $6 \mathrm{~km}$ from the summit of Mt. Etna (Rifugio Citelli; see Fig. 1), aiming to cut the plume perpendicularly. Even the measurement distance from the crater is not directly correlated to the plume age; it can be used as an indication, and a certain distance might ensure that the $\mathrm{BrO} / \mathrm{SO}_{2}$ ratio reached a temporarily equilibrium (see below). Since 2006, attempts have been made to perform more regular and frequent measurements at the same distance of $6 \mathrm{~km}$, depending on the wind direction at Rifugio Citelli (eastern flank), Rifugio Sapienza (southern flank), Mt. Maletto (western flank) or Mt. Conca (northern flank) (see map in Fig. 1). Apart from small periods in 


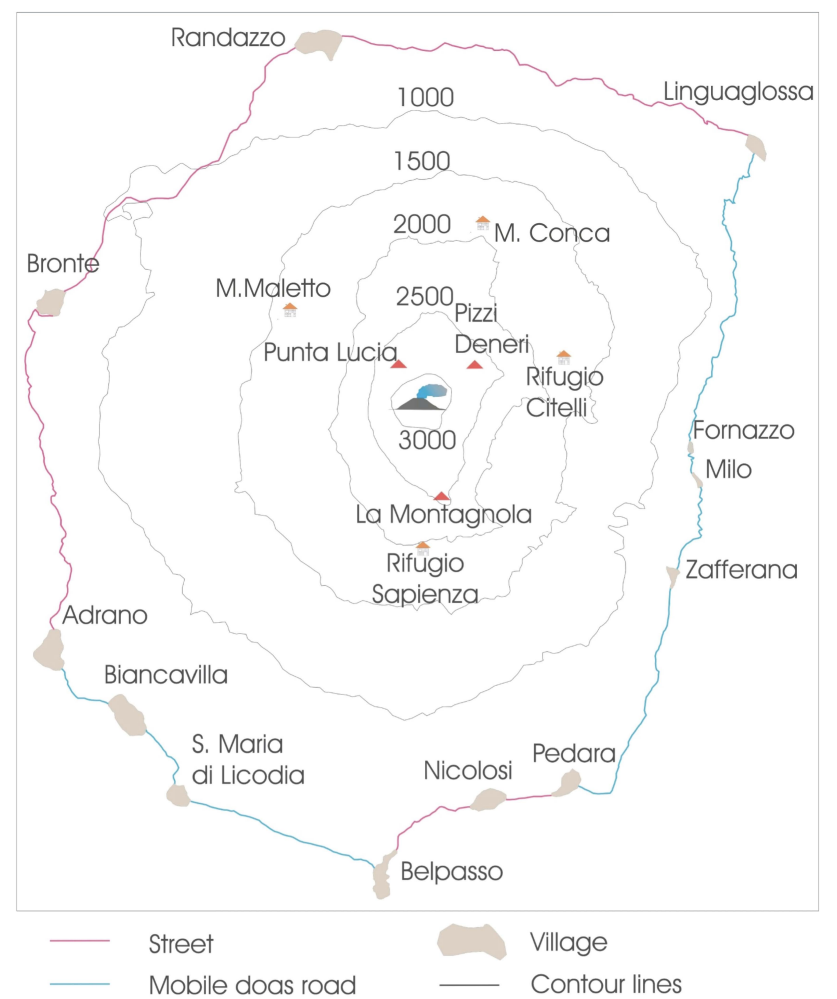

Fig. 1. Map of Mt. Etna. The small houses (Rifugio Sapienza, Rifugio Citelli, Mt. Maletto and Mt. Conca) indicate the measurements sites of the Mini-MAX-DOAS measurements at a distance of about $6 \mathrm{~km}$ from the source. The main routes for the $\mathrm{SO}_{2}$ traverses during 2006 are indicated by blue lines; in red are the rarely used routes.

which no data were taken due to instrumental failure, very bad weather condition or absence of the authors and helpers, data were collected once or several times a week for at least an hour until 2009.

The measurements for determining the $\mathrm{BrO} / \mathrm{SO}_{2}$ ratios were carried out with a scanning DOAS instrument (miniMAX-DOAS; see e.g. Bobrowski et al., 2003) in the late morning, midday or early afternoon. In the beginning of the longer eruptive periods July 2006 and May-July 2008, $\mathrm{BrO} / \mathrm{SO}_{2}$ ratios were measured with a higher frequency, about every two days.

The miniaturized MAX-DOAS system consists of an entrance optic (quartz lens, $f=40 \mathrm{~mm}, d=20 \mathrm{~mm}$, field of view approximately $10 \mathrm{mrad}$ ) coupled to a quartz fiber bundle $(4 \times 200 \mathrm{~m})$, which transmits the light into a commercial miniature spectrometer (OceanOptics Inc., USB2000). This unit is placed inside a metal box. In order to stabilize the optical bench, the entire USB2000 spectrometer (including the $\mathrm{CCD}$ detector) was cooled to a temperature about $5^{\circ} \mathrm{C}$ below ambient by a 2 -stage Peltier cascade controlled by an electronic thermostat unit built into the aluminum housing. Stabilizing the temperature of the spectrometer and detector readout electronics reduces the temperature drift of the elec- tronic offset signal. To avoid water condensation the housing is airtight and a silica gel package is added to keep the interior dry in case of leakage. An attached stepper motor is mounted on a tripod and can therefore rotate the whole unit to point the telescope to different elevation angles between 0 and $130^{\circ}$. Automatic data acquisition was performed with the software package DOASIS (Kraus et al., 2001) running on a notebook computer, or with the software PocketDOAS (Lowe, 2004) running on a small Pocket PC.

For the evaluation of the data, the software WinDoas V2.10 from IASB (Belgium Institute for Space Aeronomy, Fayt and Van Roozendael, 2001) was used to derive the slant column densities (SCD) in molecules $\mathrm{cm}^{-2}$ of $\mathrm{BrO}$ and $\mathrm{SO}_{2}$ from the recorded spectra. For the evaluation of bromine monoxide, the wavelength range $332-352 \mathrm{~nm}$ containing four absorptions was chosen. Apart from the BrO reference spectra, cross sections convoluted with a wavelengthdependent instrumental function of $\mathrm{NO}_{2}, \mathrm{O}_{3}, \mathrm{SO}_{2}, \mathrm{O}_{4}$; a "ring-spectrum" (to remove the effect of rotational Raman scattering in the atmosphere) and the FRS (Fraunhogfer reference spectrum) were simultaneously fitted to the measurement spectra using a nonlinear least squares method (Stutz and Platt, 1996). In few occasions a reference of HCHO had to be included as well, in particular due to the summer months (Vogel et al., 2012b).

For the $\mathrm{SO}_{2}$ evaluation, references of $\mathrm{SO}_{2}, \mathrm{O}_{3}$, a FRS and "ring-spectrum" were included in the fit. For more details of the $\mathrm{BrO}$ and $\mathrm{SO}_{2}$ evaluation, see Bobrowski et al. (2007) or Bobrowski and Platt (2007). The only slight difference in the $\mathrm{SO}_{2}$ evaluation was a shift in the wavelength range from $307.5-315 \mathrm{~nm}$ to $315-325 \mathrm{~nm}$, for a better signal-tonoise ratio and to better account for non-linearity effects in case of high $\mathrm{SO}_{2}$ concentrations (see also Kern et al., 2010; Bobrowski et al., 2010). Also the data of 2004 and 2005 were re-evaluated in this range for a better comparison. The whole data set is shown in Fig. 2a. Every data point in Fig. 2a presents a single measurement day and was obtained from a BrO-SO $\mathrm{SO}_{2}$ scatter plot. The adjusted $R^{2}$ of the linear fit for each scatter plot is presented in Fig. 2b, as well as the maxima for $\mathrm{BrO}$ as well as $\mathrm{SO}_{2}$ slant column densities and the mean fit error for both species. More than $61 \%$ of the data points have an adjusted $R^{2}$ of above 0.8 , and more than $96 \%$ lie above 0.5 . Fig. $2 \mathrm{c}$ shows the scatter plots for the lowest, highest and a random medium $\mathrm{BrO} / \mathrm{SO}_{2}$ ratio, respectively.

\section{Sensitivity studies}

To demonstrate the potential value of $\mathrm{BrO}$ in relation with $\mathrm{SO}_{2}$ as a tracer of changes in volcanic activity, investigations of possible environmental effects, which could influence the concentration of $\mathrm{BrO}$ and therefore the $\mathrm{BrO} / \mathrm{SO}_{2}$ ratio, must be carried out. For $\mathrm{BrO}$ this is particularly important as $\mathrm{BrO}$ is a highly reactive molecule. 


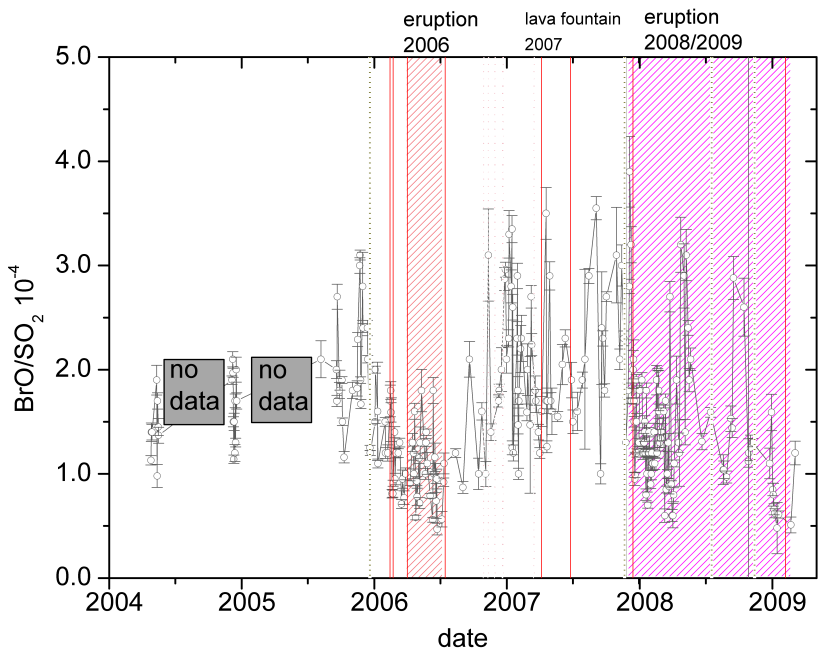

Fig. 2a. For each day, a linear fit of the $\mathrm{BrO}-\mathrm{SO}_{2}$ scatter plot was obtained. The slope of this linear fit with its standard deviation in form of an error bar is plotted as function of time. Note that the slope and its standard deviation were obtained by including the one sigma-fit error of the $\mathrm{BrO}$ evaluation in the fitting process of the linear slope. The $\mathrm{SO}_{2}$ fit error was neglected as it was small (two orders of magnitude smaller) compared to the $\mathrm{SO}_{2}$ measurement values. The potential large error due to radiative transfer issues (Kern et al., 2010) was neither for $\mathrm{SO} 2$ nor $\mathrm{BrO}$ taken into account in this study. Besides the data 2006-2009, data of 2004 and 2005 were added. Before both eruptions (2006 and 2008), an increase in the $\mathrm{BrO} / \mathrm{SO}_{2}$ ratio can be noted, followed by a general decrease in bromine monoxide in comparison to sulphur dioxide during periods of explosive and effusive volcanic activity. In 2006, the $\mathrm{BrO} / \mathrm{SO}_{2}$ ratio decreased until the end of the year and basically until the end of the enhanced activity of Etna. Also with the end of the 2008/2009 eruption, the $\mathrm{BrO} / \mathrm{SO}_{2}$ ratio stopped its decreasing trend. The eruption periods are indicated by an underlying rectangle of magenta, and higher activity events are shown by red lines. The year on the $\mathrm{x}$-axis indicates the middle of the same year. For more detailed information, see text.

As already mentioned above $\mathrm{BrO}$ is supposed to be not directly emitted by volcanoes, at least not the major part of it (e.g. Gerlach et al., 2004; Martin et al., 2006). BrO is mainly formed by interaction of the volcanic plume with the atmosphere (e.g. Oppenheimer et al., 2006; Bobrowski et al., 2007; Roberts et al., 2009; von Glasow et al., 2009).

At first sight this might lead to the conclusion that $\mathrm{BrO}$ is not a suitable parameter for volcanic activity studies, but we will show in this paper that the situation is much better than one might expect.

\subsection{Timing of bromine monoxide formation}

First experimental and model studies on the formation of $\mathrm{BrO}$ in volcanic plumes were done by Oppenheimer et al. (2006) and Bobrowski et al. (2007). Some further model studies were carried out by Martin et al. (2009), Roberts et

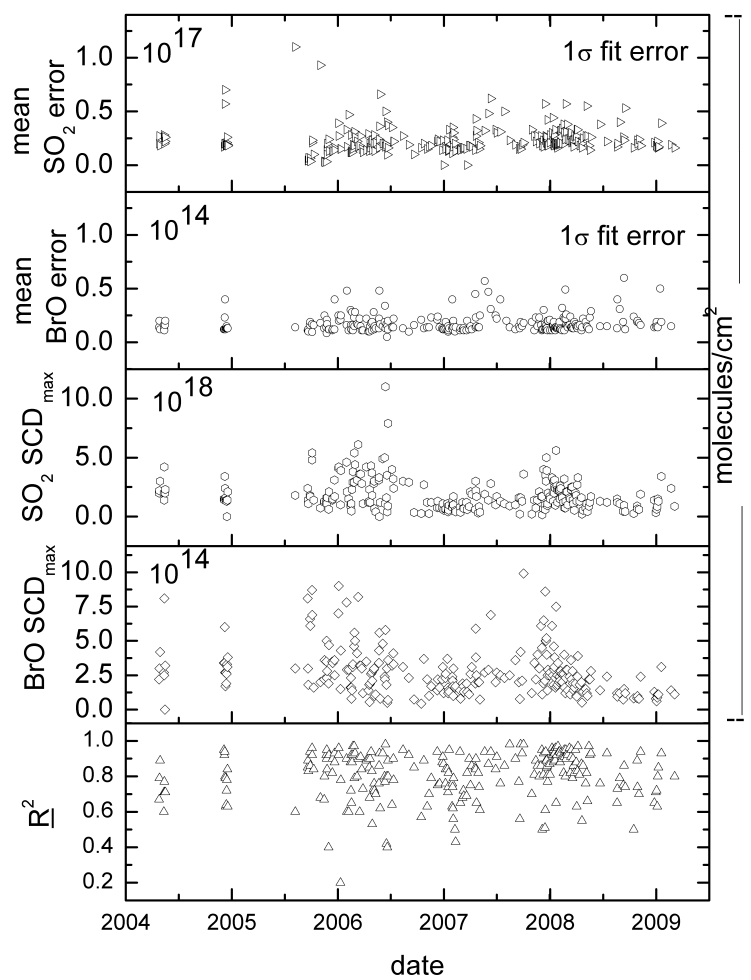

Fig. 2b. For each data point of (a), the adjusted $R^{2}$, the maximum $\mathrm{BrO}$ and $\mathrm{SO}_{2} \mathrm{SCD}$ of each measurement day as well as a mean one sigma fit error for $\mathrm{SO}_{2}$ and $\mathrm{BrO}$ are shown as a function of time.

al. (2009), von Glasow (2010) and experimental studies by Kern et al. (2008) and Vogel et al. (2010). Model and experimental data generally seem to fit, leading to the conclusion that the main reaction cycles are understood. Nevertheless, some more detailed questions remain open like the one of how much of the total emitted bromine gets converted into $\mathrm{BrO}$, or how long does the temporarily equilibrium of $\mathrm{BrO} / \mathrm{SO}_{2}$ last (e.g. Vogel et al., 2012a).

To get a more general idea about the $\mathrm{BrO}$ formation rate, we summarized in Fig. 3 already published and additionally unpublished experimental data sets available to us. The $\mathrm{BrO} / \mathrm{SO}_{2}$ ratio is presented as a function of distances, which can be used as an indirect indicator for the plume age. The plume age is controlled by distance as well as by wind velocity. We did not convert our data to plume ages because of the lack of the wind velocities, which are not available for each of the data sets. Even though we do not have an exact timing for the formation process of $\mathrm{BrO}$ for this reason, Fig. 3 shows that most of the $\mathrm{BrO}$ is formed in the first kilometres after release (corresponding to the first minutes after the gas is released). No significant additional increase of the $\mathrm{BrO} / \mathrm{SO}_{2}$ ratio can be identified at a distance larger than $5 \mathrm{~km}$ from the emission source, and nor do we see a significant decrease for the next $10 \mathrm{~km}$. This might stand in contrast to earlier published data by the first author of this 

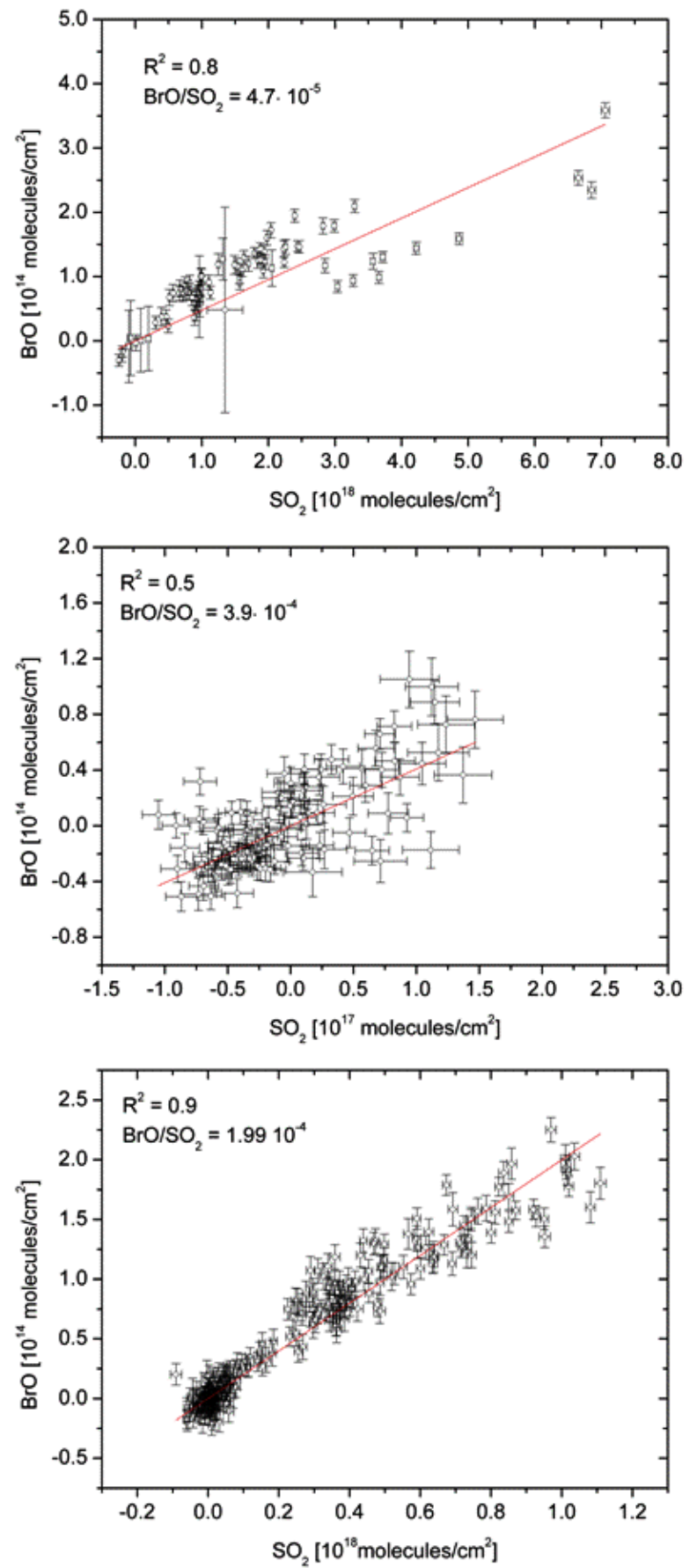

Fig. 2c. Examples of the $\mathrm{BrO}-\mathrm{SO}_{2}$ scatter plots: the scatter plot of the smallest $\mathrm{BrO} / \mathrm{SO}_{2}$ ratio, the scatter plot of the maximal $\mathrm{BrO} / \mathrm{SO}_{2}$ ratio and an example for a medium $\mathrm{BrO} / \mathrm{SO}_{2}$ scatter plot are shown, respectively.

article. The interpretation indeed has to be changed from the earlier publications where an increase of the $\mathrm{BrO} / \mathrm{SO}_{2}$ was thought to continue for more than $20 \mathrm{~km}$ as a result of model calculations. But this former interpretation was mainly caused by a lack of data or rather insufficient amounts of

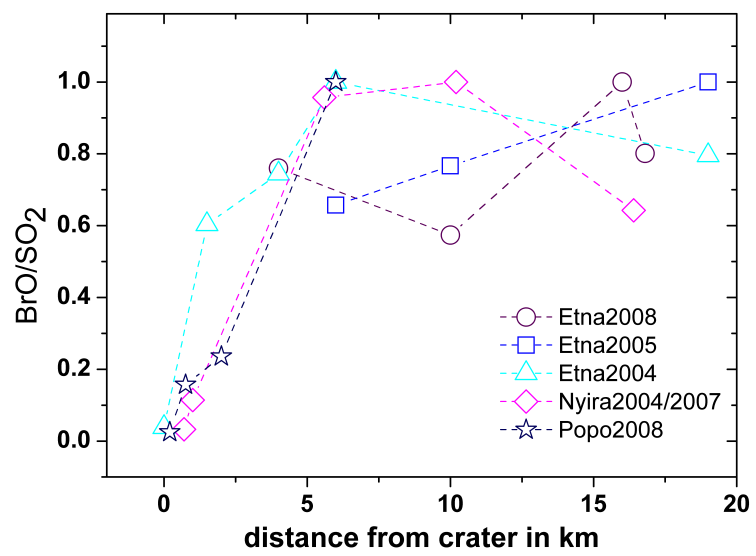

Fig. 3. $\mathrm{BrO}$ is formed by volcanic atmospheric-gas-interaction, but strong increase is (only) seen up to about $5 \mathrm{~km}$ (young plume of some minutes). $\mathrm{BrO} / \mathrm{SO}_{2}$ ratios seem to move into a plateau afterwards. The $\mathrm{BrO} / \mathrm{SO}_{2}$ ratios were normalised for a better comparison of the various sites. For more information, see text.

data. Our Fig. 3 is just an update of Fig. 4 in Bobrowski et al. (2007) including the former data set (cyan triangle Etna 2004 and blue quadrangular Etna 2005) and additional data from Nyiragongo 2004, Popocateptl 2008 and Etna 2008. Having now acquired a larger amount of $\mathrm{BrO} / \mathrm{SO}_{2}$ ratios over several distances at various volcanoes, it seems that the maximum $\mathrm{BrO} / \mathrm{SO}_{2}$ ratio might be reached in a much shorter time/closer distance from the vent than previously assumed (e.g. Bobrowski et al., 2007; Roberts et al., 2009). Afterwards the $\mathrm{BrO} / \mathrm{SO}_{2}$ ratio seems to stay constant for a while at least up to a distance of $15 \mathrm{~km}$ from the emission source, which would account for a 25-min-old plume, assuming a wind velocity of $10 \mathrm{~m} \mathrm{~s}^{-1}$.

Together with the sensitivity studies on meteorological parameters (see Sect. 3.2), we propose the assumption that, if we measure at a distance of more than $5 \mathrm{~km}$ and less than $15 \mathrm{~km}$, the $\mathrm{BrO} / \mathrm{SO}_{2}$ ratio will not vary significantly under otherwise stable conditions (no volcanic activity changes).

\subsection{Meteorological influences on $\mathrm{BrO} / \mathrm{SO}_{2}$}

Meteorological parameters often influence measured gas concentrations or gas ratios but if the dependencies are known, corrections are often possible. Therefore, the seasonal dependency and two important meteorological factors (wind velocity and humidity) were investigated.

\subsubsection{Seasonal influences on $\mathrm{BrO} / \mathrm{SO}_{2}$ ratio}

Three years of data are available for the $\mathrm{BrO} / \mathrm{SO}_{2}$ ratio at Mt. Etna. To discuss an eventual seasonal dependency of the data, the three years already displayed as one entire data set in Fig. 2 are shown in Fig. 4a-c separated for each single year, one below each other for a better comparison. During the first year, 2006, the major $\mathrm{BrO} / \mathrm{SO}_{2}$ peak was 

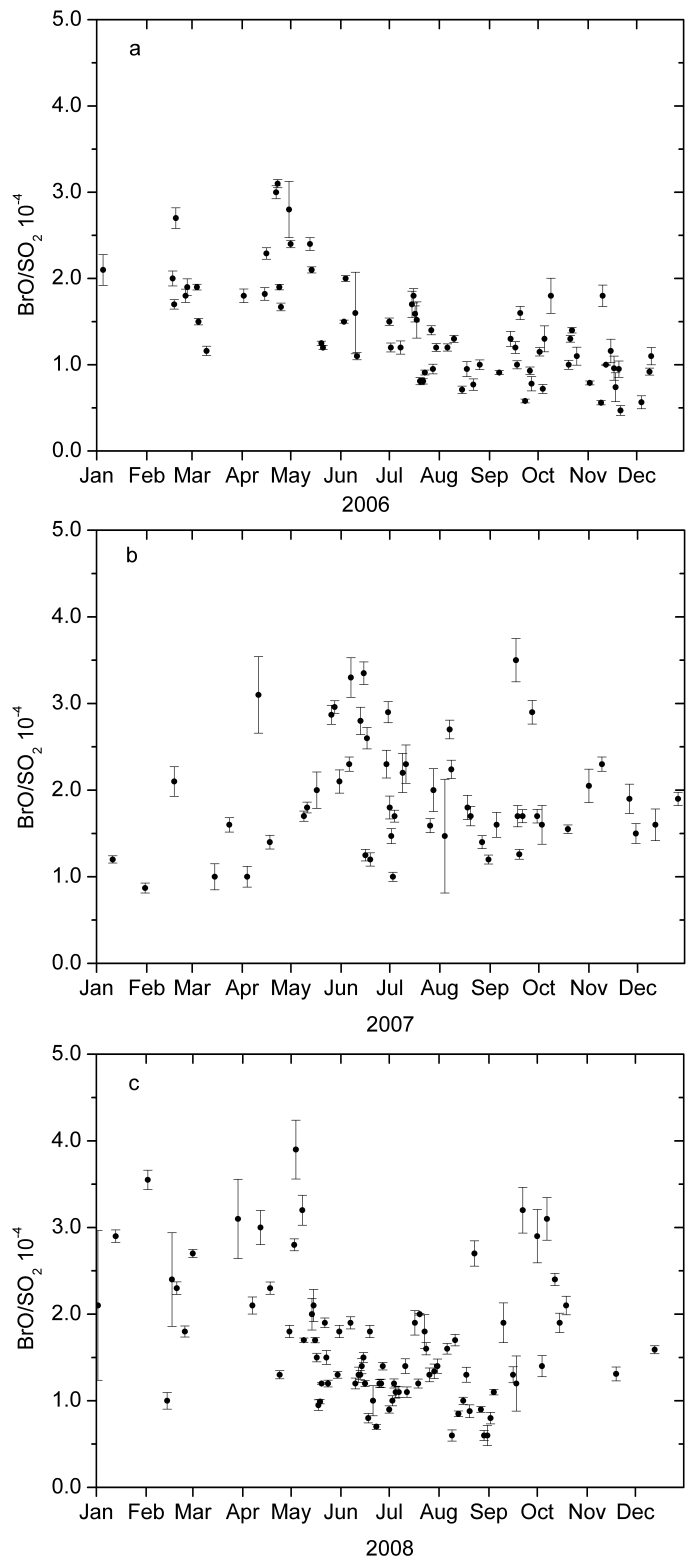

Fig. 4. $\mathrm{BrO} / \mathrm{SO}_{2}$ ratios are shown as a function of time split into three years of observations: (a) 2006-2007 highest $\mathrm{BrO} / \mathrm{SO}_{2}$ values in spring, (b) 2007-2008 highest $\mathrm{BrO} / \mathrm{SO}_{2}$ peaks during the summer, generally higher variability than under (a), and (c) 20082009 highest $\mathrm{BrO} / \mathrm{SO}_{2}$ values in spring and autumn. No periodicity of seasons can be identified. Data points and error bars calculated as in Fig. 2.

determined in April, followed by a decrease and remaining on a lower level nearly until the end of the year. In 2007 peaks can be identified during the summer months, June and September, and the graph is characterised by generally larger variations in the $\mathrm{BrO} / \mathrm{SO}_{2}$ ratio compared to 2006. In contrast to 2007 , in 2008 the summer values are of relatively low values and higher values are identified in spring 2008, like 2006 but also in autumn 2008, where $\mathrm{BrO} / \mathrm{SO}_{2}$ ratios were relatively low in autumn 2006.

No clear pattern for a variation with seasons can be identified.

\subsubsection{Wind velocity}

Wind velocity $\left(v_{\mathrm{w}}\right)$ determines the age of the plume $(t)$ at every known distance $(d)$ of the measurement to the emission source. Our measurements are carried out at a distance of around $6 \mathrm{~km}$ from the emission source (see map in Fig. 1). We attempted to scan the plume perpendicular to the wind direction. The distance from the emission source to the point of measurement is not the only parameter for determining the plume age. As already mentioned, the plume age is influenced by the wind velocity as well:

$t=d / v_{\mathrm{w}}$.

As described above, only first studies have been done regarding the question on which time scales $\mathrm{BrO}$ is formed and how fast it is decomposed again. Some more studies are in progress (e.g. Vogel et al., 2012a). All $\mathrm{BrO} / \mathrm{SO}_{2}$ ratios for our data set at Mt. Etna during 2006-2009, for which wind speeds from balloon sounding were available ${ }^{1}$, were plotted as a function of wind velocity to try to identify possible correlations. The result can be seen in Fig. 5a. No correlation could be identified. Therefore, we keep the assumption that $\mathrm{BrO}$ for a certain time frame remains in a kind of steady state.

\subsubsection{Relative humidity}

The influence of relative humidity was investigated as well. First of all, relative humidity will influence condensation and therefore influence the amount of available surfaces for heterogeneous reactions, which are essential for the bromine explosion mechanism (Wennberg, 1999), and will also influence the solubility of $\mathrm{HBr}$ in aerosols. Figure $5 \mathrm{~b}$ shows the $\mathrm{BrO} / \mathrm{SO}_{2}$ ratio as a function of humidity, and equal to the wind velocity study, no correlation can be identified. However, the relative humidity inside the volcanic plume could have been significantly different from the measurement data of the balloon sounding. Therefore, these data and the conclusion arising from it have to be taken with high caution.

Unexpectedly, neither seasonal variations nor wind velocity nor relative humidity shows a correlation to the $\mathrm{BrO} / \mathrm{SO}_{2}$ in this preliminary investigation. It is planned to do a more sophisticated study during the upcoming years, including solar irradiance, condensation conditions and wind velocity measured as close as possible to the plume.

\footnotetext{
${ }^{1}$ (http://weather.uwyo.edu/upperair/sounding.html)
} 

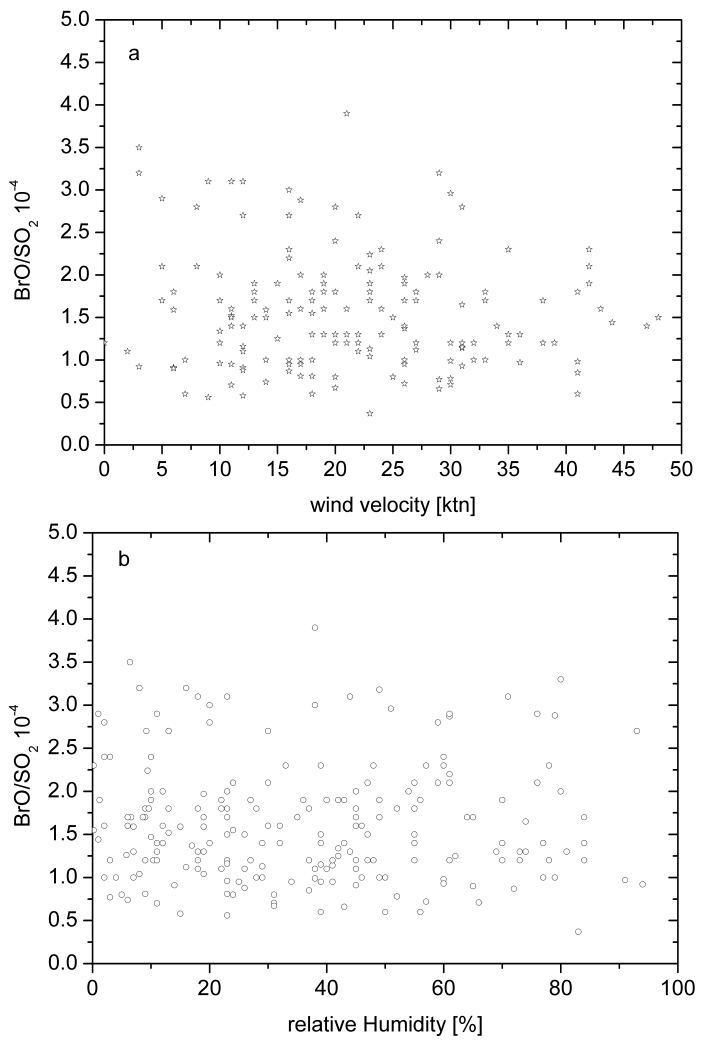

Fig. 5. (a) $\mathrm{BrO} / \mathrm{SO}_{2}$ ratio taken at a distance of about $6 \mathrm{~km}$ from the summit of Etna shown as a function of wind velocity (data taken from http://weather.uwyo.edu/upperair/sounding.html) for the day of measurements and altitude of about $3000 \mathrm{~m}$, no dependency visible. (b) $\mathrm{BrO} / \mathrm{SO}_{2}$ ratio taken at a distance of about $6 \mathrm{~km}$ from the summit of Etna shown as a function of relative humidity (data taken from http://weather.uwyo.edu/upperair/sounding.html) for the day of measurements and altitude of about $3000 \mathrm{~m}$, no dependency visible.

\section{Observations of volcanic activity between 2006 and 2009}

The beginning of 2006 was characterized by several slight ash emissions from Mt. Etna's summit craters. A bigger explosion occurred in the middle of January inside the central crater. In general mainly quiescent degassing activity could be observed at the summit craters. On 10 April 2006 some intense black ash emission was observed by the authors. In mid-July 2006, during the night of the 14 July, a new eruptive phase of Mt. Etna began. A lava flow could be seen just before midnight, and strombolian explosions started in the morning afterwards. This explosive and effusive activity continued for a week, with a peak of activity in the late evening of $20 \mathrm{July}$, when lava fountaining was observed on the southeast crater (SE crater). On 23 July 2006 all eruptive activity ended. The first signs of renewal of activity were seen at the end of August 2006. On 4 September new lava effusion took place directly coming from the top of the SE crater. During the following weeks, the activity of Etna was characterised by discontinuous lava effusions and strombolian activity at or close to the SE crater. On 12 October, a more continuous lava flow started, which lasted until the beginning of December 2006. On 26 October 2006, an additional, discontinuous lava flow started on the flank of the Bocca Nuova crater. In mid-November 2006 the volcanic activity changed its character to a more explosive one, including small pyroclastic density flows close to the SE crater (e.g. 16 November 2006), destruction and rebuilding of the main hornito at the vent of the continuous lava flow, and strong ash emissions. These ash emissions led to a closing of the airport of Catania at the end of November 2006. At the beginning of December 2006, the lava effusion stopped being continuous. The lava effusion ended probably on 13 December 2006.

On 31 March 2007, after a bit more than three months of relatively quiet degassing, a new eruptive event happened at the SE crater (strombolian explosions and lava flow) but lasted just for some hours. Similar events could be observed also on the 11 April, 29 April and 7 May 2007. In the middle of August 2007, strombolian explosions started on the flank of the SE crater and culminated in spectacular lava fountains and lava effusion in the night from 4 to 5 September 2007. On 23 November 2007 a similar event took place on the same site as on the 4 September 2007.

During the first month of 2008, small ash emissions (e.g. 14/15 February, 20 February, and 25 February) were frequently observed at the summit area and enhanced seismic activity was reported by the INGV Catania (www.ct.ingv.it). On 10 May 2008 a violent explosive phase accompanied by lava fountains and a large lava flow started in the afternoon and lasted until the evening of the same day.

Three days later on 13 May 2008 again a violent paroxysmic phase together with strong seismic activity took place, but was only poorly observed due to the bad meteorological conditions. However, this was the start of a new eruption which would last more than one year - until middle of July 2009.

The months between mid-July and beginning of November 2009 were characterized by the absence of eruptive activities. This changed on the 6 November, 2009 when a small new vent was opening on the flank of the SE crater. A red glowing light could be seen for the rest of the year from all villages on the southern and eastern flanks of Mt. Etna.

\section{Discussion and interpretation of measurement data in context with volcanological observations}

Having excluded several environmental controls on the observed variability in the $\mathrm{BrO} / \mathrm{SO}_{2}$ ratio, we propose that the observed variations of $\mathrm{BrO} / \mathrm{SO}_{2}$ ratios are primarily caused by volcanic activity changes. We hypothesise that $\mathrm{BrO} / \mathrm{SO}_{2}$ ratios can give us indications of magma dynamics due to the different solubility of bromine and sulphur in the melt, like 
Table 1. Summary of mean $\mathrm{BrO} / \mathrm{SO}_{2}$ values during the various time periods as described in the text. The table also displays the number of data points available for the various time frames.

\begin{tabular}{lrrl}
\hline Time period & $\begin{array}{r}\mathrm{BrO} / \mathrm{SO}_{2} \\
\text { mean }\end{array}$ & $\begin{array}{r}\text { Number of data } \\
\text { points included }\end{array}$ & Volcanic activity \\
\hline September-October 2004 & $\begin{array}{r}1.4 \times 10^{-4} \\
1.8 \times 10^{-4}\end{array}$ & 40 & eruptive period \\
Between May 2005-July 2006 & 35 & eruptive period \\
July-December 2006 & $1.1 \times 10^{-4}$ & 71 & non-eruptive period \\
January 2007-May 2008 & $2.1 \times 10^{-4}$ & 85 & eruptive period \\
May 2008-June 2009 & $1.4 \times 10^{-4}$ & 8 & 3 month before eruption \\
April 2006 & $2.3 \times 10^{-4}$ & 4 & 1 month before eruption \\
June 2006 & $1.6 \times 10^{-4}$ & 7 & 1 month before eruption \\
June 2007 & $2.4 \times 10^{-4}$ & 6 & 2 month before eruption \\
August 2007 & $1.8 \times 10^{-4}$ & 2 & 1 month before eruption \\
September 2007 & $2.1 \times 10^{-4}$ & 5 & 3 month before eruption \\
October 2007 & $1.6 \times 10^{-4}$ & 5 & 1 month before eruption \\
February 2008 & $2.2 \times 10^{-4}$ & & \\
April 2008 & $2.1 \times 10^{-4}$ & &
\end{tabular}

a August 2006 is not included as eruptive period.

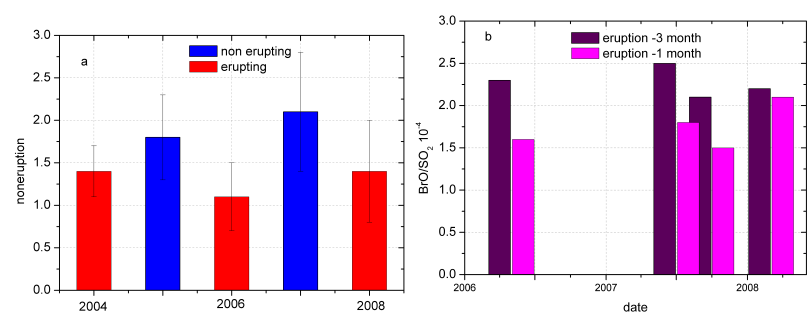

Fig. 6. (a) Measurement data were averaged for eruptive and noneruptive periods. The $\mathrm{BrO} / \mathrm{SO}_{2}$ mean is plotted as function of time. Eruptive data are presented as red columns and non-eruptive data as blue columns. Although this is only a small statistical approach, it demonstrates that during eruptions lower $\mathrm{BrO} / \mathrm{SO}_{2}$ ratios have been measured. (b) Additionally to (a) mean $\mathrm{BrO} / \mathrm{SO}_{2}$ values of the third month before the eruption (violet columns) and mean $\mathrm{BrO} / \mathrm{SO}_{2}$ values of the month just before the eruption (magenta columns) have been compared for the four eruptive events described in the text. Clear enhanced mean $\mathrm{BrO} / \mathrm{SO}_{2}$ values are determined for the third month before the eruption and smaller mean $\mathrm{BrO} / \mathrm{SO}_{2}$ values the month before the eruption (see also Table 1).

other gases do as well (e.g. Spilliaert et al., 2006). Due to the absence of model studies and experimental measurements regarding the solubility of bromine in Etnean melt, we can only draw interpretations using an empirical approach.

After a short description of the principal $\mathrm{BrO} / \mathrm{SO}_{2}$ variations in context of volcanic activity (see also Figs. 6 and 7 and Table 1 for a summarizing overview), we present an interpretation of our 3-yr data set of the $\mathrm{BrO} / \mathrm{SO}_{2}$ ratios, comparing their variations with our visual observations and already by other authors' published geophysical data.

As partly described above, May 2005 (after the end of the 2004/2005 eruption in March 2005) and the beginning of
2006 as well as 2007 are assumed to be periods of relatively quiescent degassing (Fig. 7a). That is not completely true for the beginning of 2006 where at least one bigger explosion took place in Mt. Etna's summit region in the middle of January 2006. However, in the context of the limited time series of our measurements and visual observations, these were periods of relatively calm volcanic activity of Mt. Etna. During non-eruptive periods we measured a mean $\mathrm{BrO} / \mathrm{SO}_{2}$ ratio of about $2 \times 10^{-4}$ (Fig. 7a). In comparison to this value, we observed relatively high $\mathrm{BrO} / \mathrm{SO}_{2}$ ratios three months before the eruption in 2006 and 2008. Mean values for the third month before the eruption are shown as violet columns in Fig. 6b. In April 2006 the $\mathrm{BrO} / \mathrm{SO}_{2}$ ratio reached $3.1 \times 10^{-4}$ (see Fig. 2). In the middle of February and May 2008, again a high $\mathrm{BrO} / \mathrm{SO}_{2}$ ratio $>3 \times 10^{-4}$ was determined, $3.6 \times 10^{-4}$ and $3.9 \times 10^{-4}$, respectively as shown in Fig. 2. Also before the events of lava fountaining in 2007, we measured before the two most violent cases an increase of the $\mathrm{BrO} / \mathrm{SO}_{2} \mathrm{ra}-$ tio to over $3 \times 10^{-4}$. First, in June $2007 \mathrm{BrO} / \mathrm{SO}_{2}$ values reached $3.2 \times 10^{-4}$ followed by lava fountaining and a lava flow three months later on 4 September 2007. In the middle of September 2007, a second increase of $\mathrm{BrO} / \mathrm{SO}_{2}$ to $3.5 \times 10^{-4}$ was again preceding lava fountaining combined with lava effusion two month later - on 23 November 2007.

During the investigated period in this work, 2006 to 2009 , the described maxima of the $\mathrm{BrO} / \mathrm{SO}_{2}$ ratios were usually followed by a decreasing trend until the start of the eruptive activities. Figure $6 \mathrm{~b}$ mirrors this decrease by showing the mean $\mathrm{BrO} / \mathrm{SO}_{2}$ ratios one month before the eruption (columns in magenta) - June 2006, August 2007, October 2007, and April 2008. A certain exception is the 2008 eruption, when $\mathrm{BrO} / \mathrm{SO}_{2}$ remained relatively high until shortly before the start of the eruption. With the start of eruptive 

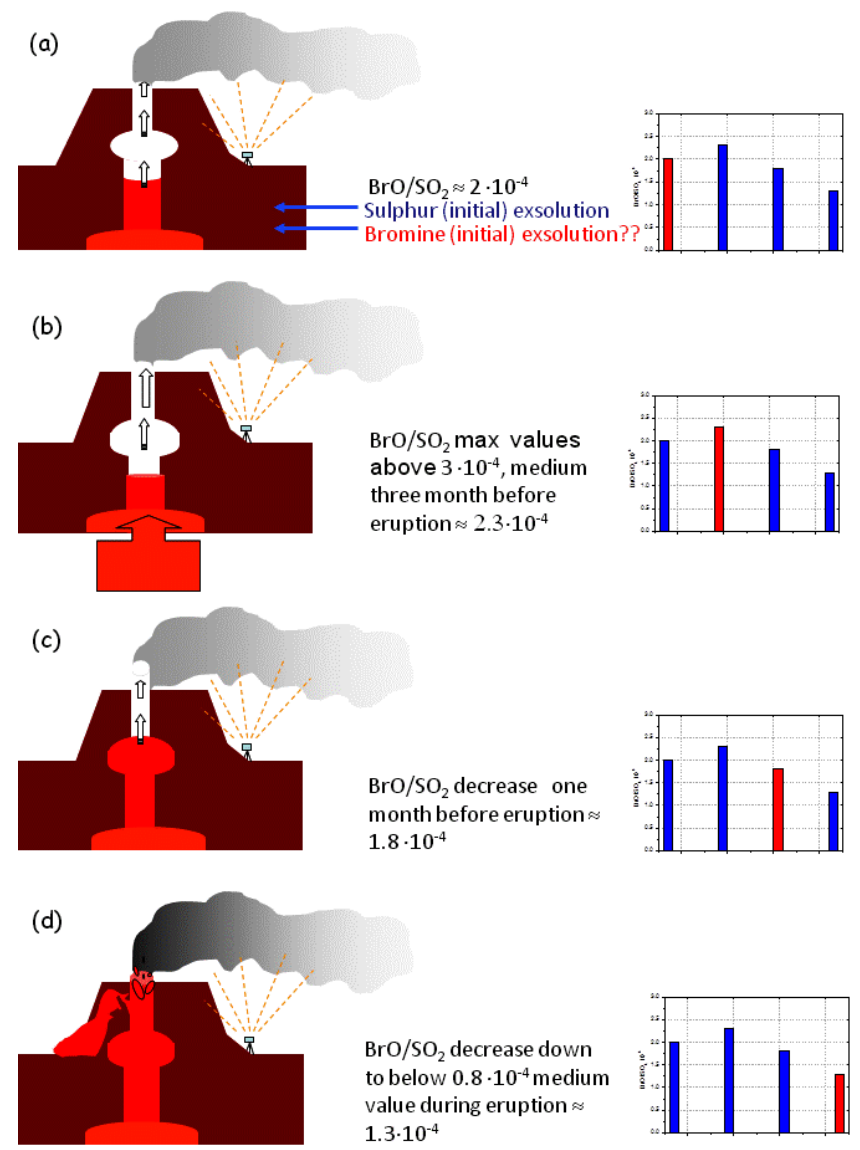

Fig. 7. Sketch of the empirical model. (a) In contrast to chlorine and fluorine, we assume that bromine is less soluble in the magmatic melt than sulphur. The mean value of non-eruptive periods during 2006-2009 is around $2 \times 10^{-4}$. (b) Assuming bromine is less soluble in magmatic melt than sulphur, bromine starts to be released earlier in comparison to sulphur when fresh magma is rising up - maxima $\mathrm{BrO} / \mathrm{SO}_{2}$ ratios rise over $3 \times 10^{-4}$. The mean value is around $2.3 \times 10^{-4}$ in month three before the 2006 and 2008 eruptions as well as in month three and two before the two violent lava fountaining events in 2007. (c) When magma is rising further, sulphur starts to be released and might overtake bromine; $\mathrm{BrO} / \mathrm{SO}_{2}$ ratios decrease ( $\mathrm{SO}_{2}$ fluxes should increase). The mean $\mathrm{BrO} / \mathrm{SO}_{2}$ value of the last month before the observed eruption is $1.8 \times 10^{-4}$. (d) Further decrease - no further magma rise from below, and melt already depleted in bromine; sulphur out-gasing is determining the ratio. The lowest $\mathrm{BrO} / \mathrm{SO}_{2}$ value during eruptions observed was $0.47 \times 10^{-4}$. The mean $\mathrm{BrO} / \mathrm{SO}_{2}$ ratio was calculated at $1.3 \times 10^{-4}$.

activities, the $\mathrm{BrO} / \mathrm{SO}_{2}$ ratio mainly continued to decrease at least for the activities in 2006 (and 2007). For the 2008/2009 eruption, we observed a more variable $\mathrm{BrO} / \mathrm{SO}_{2}$ ratio. However, also during the 2008/2009 eruption, the mean $\mathrm{BrO} / \mathrm{SO}_{2}$ ratio was with $1.4 \times 10^{-4}$ significantly lower than during the non-eruptive period before with a mean value of $2.1 \times 10^{-4}$. The mean $\mathrm{BrO} / \mathrm{SO}_{2}$ ratio was even lower $-1.1 \times 10^{-4}$ during the eruption of 2006. Figure 6a shows the mean values dur- ing the eruptions as red columns, and the mean ratios of noneruptive periods are displayed as blue columns. For a summary of the described $\mathrm{BrO} / \mathrm{SO}_{2}$ ratio in relation to Etna's activity, see also Table 1 which describes the mean values for the various time frames.

In the following for an interpretation of our data, we assume that bromine, in contrast to the more frequently studied halogens - chlorine and fluorine, would be less soluble in the melt than sulphur. With this hypothesis we can interpret our time series as illustrated in Fig. 7 by including our visual observations and geophysical data published by e.g. Bonforte et al. (2008), Aloisi et al. (2009), Aiuppa et al. (2010), Bonaccorso et al. (2011).

Assuming that bromine is less soluble in magmatic melt than sulphur, bromine should be emitted earlier compared to sulphur when fresh magma is rising up. Therefore, an increase of the $\mathrm{BrO} / \mathrm{SO}_{2}$ ratios would be expected in the first phase of magma rising (Fig. 7b).

In the investigated period increasing $\mathrm{BrO} / \mathrm{SO}_{2}$ ratios were determined slightly after ash emissions and enhanced seismic activities were reported from the INGV Catania (www.ingv. ct.it) in February/March 2006 and in January/February 2008, respectively. These activities could have been caused due to magma movements or changes in the conduit systems. After the eruption of 2004/2005, an inflation of the volcano before the 2006 eruption had been observed (Bonforte et al., 2008; Bonaccorso et al., 2011) which was interpreted as a period of new magma uprise. For our data set that could mean that magma reached in April 2006 the level where a significant amount of bromine starts to be exsolved. Aloisi et al. (2009) and also Aiuppa et al. (2010) document a further recharging phase of Mt. Etna starting in the beginning of 2007 which led to the eruption in 2008. In Bonforte et al. (2008) and Aiuppa et al. (2010), the authors present among others displacement data. Comparing the displacement data shown in Fig. 2c of Aiuppa et al. (2010) with the $\mathrm{BrO} / \mathrm{SO}_{2}$ ratios in Fig. 2 of this article, the two maxima in 2007 before the lava fountain events (September and November 2007) as well as the general increasing trend from the beginning 2007 to May 2008 can be observed for both data sets - displacement data and $\mathrm{BrO} / \mathrm{SO}_{2}$ ratios.

Furthermore, the decrease of $\mathrm{BrO} / \mathrm{SO}_{2}$ ratios, which started already some months before the eruptive events that took place in 2006 and in 2007, can be explained in our model if we assume that magma continues to rise without further new magma replacements from below (see Fig. 7c). Sulphur therefore started to be emitted in larger amounts as well and might have overtaken bromine. Therefore, the $\mathrm{BrO} / \mathrm{SO}_{2}$ ratio decreased. Even if the bromine emissions were still high, at higher $\mathrm{SO}_{2}$ fluxes a decreasing $\mathrm{BrO} / \mathrm{SO}_{2}$ ratio would be expected. For the 2006 eruption we indeed measured an increase of $\mathrm{SO}_{2}$ fluxes already before the eruption started, during the period of already decreasing $\mathrm{BrO} / \mathrm{SO}_{2}$ ratios (Giuffrida et al., 2007), and determining still high "BrO 
fluxes" 2 if we calculate a "BrO flux" by multiplying the $\mathrm{BrO} / \mathrm{SO}_{2}$ ratio with a parallel measured $\mathrm{SO}_{2}$ flux.

With the start of eruptions, the $\mathrm{BrO} / \mathrm{SO}_{2}$ ratio continues to decrease in our data at least for the activities in 2006 (and 2007), which we explain with the fact that no new magma uprise occurred (Fig. 7d). An explanation could be a melt previously depleted in bromine that is still relatively rich in sulphur, and therefore the $\mathrm{BrO} / \mathrm{SO}_{2}$ values were continuing to diminish.

After the onset of the 2008/2009 eruption, we observed a more variable $\mathrm{BrO} / \mathrm{SO}_{2}$ ratio, which could be explained assuming magma movements from a deeper source to more shallow reservoirs also after the beginning of the eruption. A further indication for this interpretation is that our higher $\mathrm{BrO} / \mathrm{SO}_{2}$ values in October 2008 during the ongoing eruption are observed simultaneously with an increased seismic activity in the beginning of September and October 2008 reported by INGV Catania.

We just showed that assuming an earlier bromine excess from the magmatic melt than sulphur we can describe our data set in accordance with several other observations and already published data. An exception would be, but only in some details, the work of Aiuppa et al. (2007). There the authors published a 2-yr data set of $\mathrm{CO}_{2} / \mathrm{SO}_{2}$ ratios of the Voragine crater, one of the four summit craters at Mt. Etna. Aiuppa and co-workers conclude from their data that magma started not to rise before May 2006 and a stagnant and non-convective magma body inside the Etnean edifice is still considered in spring 2006. Examining the reported the $\mathrm{CO}_{2} / \mathrm{SO}_{2}$ ratios, this appears to be a natural conclusion and we do not want to rule it out. But it is in contrast to our interpretation of our own data set, where magma movements took place already before May 2006. Some facts should be pointed out. First, a stagnant and non-convective magma body does not necessarily fit with enhanced seismic activity and ash emission in spring 2006 (www.ingv.ct.it and observation of ash emission by N. Bobrowski in April 2006 and Bonaccorso et al., 2011). Second, the authors have just one data point for the whole month of April 2006, which could have led to a misleading interpretation. Third, in contrast to our measurements of a mixed plume from all craters, the authors were observing gas emissions of the Voragine crater which made up a minor part to the total budget in the investigated time period, and it is quite uncertain if the Voragine crater was involved in the eruptive activity in 2006. Further, La Spina at al. (2010) presented spectroscopic measurements taken at Mt. Etna and proposed a model showing that shortterm variations in $\mathrm{CO}_{2} / \mathrm{SO}_{2}$ ratios at a single crater can occur due to minor variations in the magma/gas flux entering each conduit branch of the various craters, without an overall change in magma supply. La Spina et al. (2010) mentioned

\footnotetext{
${ }^{2} \mathrm{BrO}$ is not a primarily emitted volcanic gas, but rather formed in an ageing plume. Talking about a $\mathrm{BrO}$ flux is therefore not correct in a literal sense.
}

also the fact that variations measured at individual craters may be unrepresentative of the volcanic system and require cautious interpretation. However little the contrast in interpretations is, it makes clear that future studies and collaborations are necessary to improve our understanding of the real processes inside Mt. Etna. In general $\mathrm{CO}_{2} / \mathrm{SO}_{2}$ ratios and $\mathrm{BrO} / \mathrm{SO}_{2}$ ratios seem to behave similarly, for instance by comparing $\mathrm{CO}_{2} / \mathrm{SO}_{2}$ values for the period (2007-2009) investigated by Aiuppa et al. (2010) with the data presented in this work. Both show maxima some months before the lava fountain events in 2007 and also a tendency to increase during the first month of 2008 prior the start of the eruption. However, the tendency of a slow increase from the beginning of 2007 to May 2008 is shown by the $\mathrm{BrO} / \mathrm{SO}_{2}$ ratios and the displacement study, but not in the $\mathrm{CO}_{2} / \mathrm{SO}_{2}$ ratios. All the mentioned points are in agreement with our hypothesis of a lower solubility of bromine in comparison to sulphur.

Nevertheless, if we try to interpret our data set assuming that bromine behaves similarly to chlorine and fluorine, therefore having a higher solubility in melt than sulphur, we run into some contradictions with visual and geophysical observations rather quickly. Thus, after a period of quiescent degassing and a relatively constant $\mathrm{BrO} / \mathrm{SO}_{2}$ ratio of $2 \times 10^{-4}$, an increase in the $\mathrm{BrO} / \mathrm{SO}_{2}$ ratio could be interpreted as a decline of $\mathrm{SO}_{2}$ degassing due to a magma rather depleted in its gas content. This is neither the case for 2006 nor for the 2007 eruptive events, as the $\mathrm{SO}_{2}$ fluxes (see Giuffrida et al., 2007; Salerno et al., 2009 and weekly reports www.ct.ingv.it) as well as the inflation of the volcanic system are in disagreement with such an interpretation. If we ignore this fact for a moment, the following decrease before the eruption could be caused by an increasing $\mathrm{SO}_{2}$ emission due to the arrival of new magma. For the 2006 and the 2007 events, this may be reasonable. For the start of the 2008 eruption, this would mean that the new magma arrives instantaneously with the start of the eruption or that the gas emissions were blocked due to a sealing of the summit craters. The first assumption is highly improbable and also in contrast to e.g. Aiuppa et al. (2010) and Aloisi et al. (2009). The second one is also in disagreement with reported $\mathrm{SO}_{2}$ flux data of INGV Catania (www.ct.ingv.it). Already at this point we see that there are difficulties with the hypothesis that bromine is more soluble in the magmatic melt than sulphur, and we fail if we attempt to interpret our data in a logical way. With our current knowledge, we conclude that the hypothesis of a higher solubility of bromine in a basaltic melt in comparison to sulphur is less probable than our earlier hypothesis.

\section{Conclusions}

A "long" time series of relatively frequent MAX-DOAS measurements was obtained to investigate variations of $\mathrm{BrO} / \mathrm{SO}_{2}$ ratios as a function of volcanic activity changes. First sensitivity studies to check with non-volcanic 
parameters were carried out, with none of them yielding any kind of dependency. We still cannot answer how much of the total emitted bromine in whatever form emitted gets converted into $\mathrm{BrO}$ and how long these transformation processes exactly need under the various ambient conditions. We still need detailed studies, in which other molecules containing bromine are measured simultaneously and the bromine content of aerosol is determined with increasing distance from the source. However, even without knowing the percentage of $\mathrm{BrO}$ of the total emitted bromine, we show measurements that lead to the assumption that the ratio of $\mathrm{BrO}$ to total emitted bromine does not change in a certain range of plume ages, which is quite commonly used for measurements. If we want to use $\mathrm{BrO}$ as a tracer of emission changes, it is of minor importance if only $5 \%$ or even $70 \%$ are converted to $\mathrm{BrO}$ as long as this relation is constant.

We have proposed a provocative hypothesis, by assuming that bromine releases earlier from a magmatic melt than sulphur. This is in contrast to the more well-studied halogens chlorine and fluorine. However, it explains our data set well. Our empirical model based on this hypothesis explains the evolution of the ratio well in relation to our observations and other previously published data. Maxima $\mathrm{BrO} / \mathrm{SO}_{2}$ ratios were observed some months prior to eruptive events when magma was rising up the conduit, and particular low values are seen during eruptive events when the new magma body becomes exhausted in its bromine content.

Unfortunately, very few laboratory experiments have been performed to investigate the behaviour of bromine in melts. Such experiments are required in order to test the hypothesis proposed here. The relative simplicity of the plume $\mathrm{BrO} / \mathrm{SO}_{2}$ measurement using UV spectroscopy suggests that this parameter could be added to the group of measurements which sheds light on the magma dynamics controlling volcanic activity. It is therefore clear that further laboratory and field studies on bromine could yield useful results for volcanologists.

Acknowledgements. We like to thank all persons who were assisting us in the field, especially Nuccio Faro, who helped a lot with the acquisition of the MAX-DOAS data. We further thank Christoph Hörmann, Johannes Zielcke and Peter Lübcke for critical questions on the interpretation and improvements of English wording in this manuscript and we thank M. Edmonds and an anonymous reviewer as well as M. Burton as Editor for their comments and helpful advices to improve the manuscript.

Edited by: M. Burton

\section{References}

Aiuppa, A.: Degassing of halogens from basaltic volcanism: insights from volcanic gas observations, Chem. Geol., 263, 99109, 2009.

Aiuppa, A., Federico, C., Paonita, A., Pecoraino, G., and Valenza, M.: $\mathrm{S}, \mathrm{Cl}$ and $\mathrm{F}$ degassing as an indiator of volcanic dynamics: The 2001 eruption of Mt. Etna, Geophys. Res. Lett., 29, 15591562, doi:10.1029/2002G1015032, 2002.

Aiuppa, A., Federico, C., Giudice, G. Gurrieri, S., Paonita, A., and Valenza, M.: Plume chemistry provides insights into mehanisms of sulfur and halogen degassing in basaltic volcanoes, Earth Planet. Sci. Lett., 222, 469-483, 2004.

Aiuppa, A., Federico, C., Franco, A., Giudice, G., Gurrieri, S., Inguaggiato, S., Liuzzo, M., McGonigle, A. J. S., and Valenza, M.: Emission of bromine and iodine from Mount Etna volcano, Geochem. Geophy. Geosy., 6, Q08008, doi:10.1029/2005GC000965, 2005.

Aiuppa, A., Moretti, R., Federico, C., Gaetano, G., Gurrieri, S., Liuzzo, M., Papale, P., Shinohara, H., and Valenza, M.: Forecasting Etna eruptions by real-time observation of volcanic gas composition, Geology, 35, 1115-1118, 2007.

Aiuppa, A., Baker, D. R., and Webster, J. D.: Halogens in volcanic systems, Chem. Geol., 263, 1-18, doi:10.1016/j.chemgeo.2008.10.005, 2009.

Aiuppa, A., Cannata, A., Cannavò, F., Di Grazia, G., Ferrari, F., Giudice, G., Gurrieri, S., Liuzzo, M., Mattia, M., Montalto, P., Patanè, D., and Puglisi, G.: Patterns in the recent 2007-2008 activity of Mount Etna volcano investigated by integrated geophysical and geochemical observations, Geochem. Geophy. Geosy., 11, Q09008, doi:10.1029/2010GC003168, 2010.

Alletti, M., Baker, D., and Freda, C.: Halogen diffusion in basaltic melts, Geochim. Cosmochim. Ac., 71, 3570-3580, 2007.

Aloisi, A., Bonaccorso, A., Cannavò, F., Gambino, S., Mattia, M., Puglisi, G., and Boschi, E.: A new dyke intrusion style for the Mount Etna May 2008 eruption modelled through continuous tilt and GPS data, Terra Nova, 21, 316-321, doi:10.1111/j.13653121.2009.00889.x, 2009.

Bobrowski, N., Hönninger, G., Galle, B., and Platt, U.: Detection of Bromine Monoxide in a Volcanic Plume, Nature, 423, 273-276, 2003.

Bobrowski, N. and Platt, $\mathrm{U}$.: $\mathrm{SO}_{2} / \mathrm{BrO}$ ratios studied in five volcanic plumes, J. Volcanol. Geothe. Res., 166, 147-160, 2007.

Bobrowski, N., Louban, I., von Glasow, R., Whaba, O. I., Platt, U., Aiuppa, A., and Inguaggiato, S.: Bromine chemistry in volcanic plumes, J. Geophys. Res., 112, D06311, doi:10.1029/2006JD007206, 2007.

Bobrowski, N., Vogel, L., Kern, C., Giuffrida, G. B., DelgadoGranados, H., and Platt, U.: Bromine oxidation in volcanic plumes Volcanic plumes, EGU, Vienna, 2009.

Bobrowski, N., Kern, C., Platt, U., Hörmann, C., and Wagner, T.: Novel $\mathrm{SO}_{2}$ spectral evaluation scheme using the 360$390 \mathrm{~nm}$ wavelength range, Atmos. Meas. Tech., 3, 879-891, doi:10.5194/amt-3-879-2010, 2010.

Bonaccorso, A. Bonforte, A., Calvari, S., Del Negro, C., Di Grazia, G., Ganci, G., Neri, M., Vicari, A., and Boschi, E.: The initial phases of the 2008-2009 Mount Etna eruption: A multidisciplinary approach for hazard assessment, J. Geophys. Res., 116, B03203, doi:10.1029/2010JB007906, 2011. 
Bonforte, A., Bonaccorso, A., Guglielmino, F., Palano, M., and Puglisi, G.: Feeding system and magma storage beneath Mt. Etna as revealed by recent inflation/deflation cycles, J. Geophys. Res., 113, B05406, doi:10.1029/2007JB005334, 2008.

Bureau, H., Kepler, H., and Metrich, N.: Volcanic degassing of bromine and iodine: experimental fluid/melt partitioning data and applications to stratospheric chemistry, Eart Planet. Sci. Lett., 183, 51-60, 2000.

Burton M., Allard P., Murè F., and Oppenheimer C.: FTIR remote sensing of fractional magma degassing at Mount Etna, Sicily, in: Volcanic Degassing, edited by: Oppenheimer, C., Pyle, D. M., and Barclay, J., Special Publications, 213, 281-293, Geological Society, London, 2003.

Burton, M. R., Allard, P., Murè, F., and La Spina, A.: Magmatic Gas Composition Reveals the Source Depth of SlugDriven Strombolian Explosive Activity, Science, 317, 227, doi:10.1126/science.1141900, 2007.

Burton, M. R., Allard, P., La Spina, A., and Murè, F.: One decade of OP-FTIR monitoring of Mount Etna gas plume emissions: lessons and implications, EGU, Vienna, 2010.

Caltabiano, T., Burton, M., Giammanco, S., Allard, P., Bruno, N., Mure, F., and Romano R.: Volcanic Gas Emission from the Summit Craters and Flanks of Mt. Etna, 1987-2000 in: Mt. Etna: Volcano Laboratory, edited by: Bonaccorso, A., Calvari, S., Coltelli, M., Del Negro, C. and Falsaperla, S., American Geophysical Union Geophysial Monograph, 143, 111-128, 2004.

Carroll, M. R. and Holloway, J. R.: Volatiles in Magmas, Washington: Mineralogical Society of America, 1994.

Edmonds, M., Pyle, D. M., and Oppenheimer, C.: A model for degassing at Soufrière Hills Volcano, Montserrat, West Indies, based on geochemical data, Earth Planet Sci. Lett., 186, 159173,2001

Edmonds, M., Gerlach, T. M., and Herd, R. A.: Halogen degassing during ascent and eruption of water-poor basaltic magma, Halogens in Volcanic Systems and Their Environmental Impacts, ISSN 0009-2541, Chem. Geol., 263, 122-130, doi:10.1016/j.chemgeo.2008.09.022, 2009.

Fayt, C. and van Roozendael, M.: WinDOAS 2.1 - Software User Manual. Belgisch Instituut voor Ruimte-Aeronomie Institut d'Ae'ronomie Spatiale de Belgique, Brussels, Belgium, 2001.

Francis, P., Burton, M. R., and Oppenheimer, C.: Remote measurements of volcanic gas composition by solar occultation spectroscopy, Nature, 396, 567-570, 1998.

Gerlach, T. M.: Volcanic sources of tropospheric ozonedepleting trace gases, Geochem. Geophy. Geosy., 5 , Q09007, doi:10.1029/2004GC000747, 2004.

Giuffrida, G. B., Bobrowski, N., Vita, F., Sollami, A., and Inguaggiuato, S.: $\mathrm{BrO} / \mathrm{SO}_{2}$ studies at Mt. Etna during 2006 and 2007, AGU, San Francisco, USA, 2007.

Horrocks, L. A., Oppenheimer, C., Burton, M. R., and Duffell, H. $\mathrm{J}$. : Compositional variation in tropospheric volcanic gas plumes: evidence from ground-based remote sensing, in: edited by: Oppenheimer, C., Pyle, D. M., and Barclay, J., Volcanic degassing., Geol. Soc., London, Special Publication, 213, 349-369, 2003.

Kern, C., Sihler, H., Vogel, L., Rivera, C., Herrera, M., and Platt, U.: Halogen oxide measurements at Masaya volcano, Nicaragua using active long path differential optical absorption spectroscopy, B. Volcanol., 71, 659-670, doi:10.1007/s00445008-0252-8, 2008.
Kern, C., Deutschmann, T., Vogel, L., Wöhrbach, M.., Wagner, T., and Platt, U.: Radiative transfer corrections for accurate spectroscopic measurements of volcanic gas emissions, B. Volcanol., 72, 233-247, doi:10.1007/s00445-009-0313-7, 2010.

Kraus, S.: DOASIS, DOAS Windows Software. Presentation at the 1st international DOAS Workshop, 13-14 September 2001, Heidelberg, Germany, 2001.

La Spina, A., Burton, M. R., and Salerno, G.:Unravelling the processes controlling gas emissions from the central and northeast craters of Mt. Etna, J. Volcanol. Geoth. Res., 198, 368-376, 2010.

Lowe, G.: PocketDOAS Manuel, University of Heidelberg, 2004.

Martin, R. S., Mather, T. A., and Pyle, D. M.: High-temperature mixtures of magmatic and atmospheric gases, Geochem. Geophy. Geosy., 7, Q04006, doi:10.1029/2005GC001186, 2006.

Martin, R. S., Roberts, T. J., Mather, T. A., and Pyle, D. M.: The implications of $\mathrm{H}_{2} \mathrm{~S}$ and $\mathrm{H}_{2}$ stability in high-T mixtures of magmatic and atmospheric gases for the production of oxidized trace species (e.g., BrO and $\mathrm{NO}_{\mathrm{x}}$ ), Chem. Geol., 263, 143-150, 2009.

Menyailov, I. A.: Prediction of eruptions using changes in composition of volcanic gases, B. Volcanol., 39, 112-125, 1975.

Moretti, R., Papale, P., and Ottonello, G.: A model for the saturation of C-O-H-S fluids in silicate melts, in: Volcanic degassing, edited by: Oppenheimer, C., Pyle, D. M., and Barclay, J., Geological Society of London Special Publication, 213, 81-101, 2003.

Noguchi, K. and Kamiya, H.: Prediction of volcanic eruption by measuring the chemical composition and amounts of gases, B. Volcanol., 26, 367-378, 1963.

Oppenheimer, C. and Kyle, P. R.: Probing the magma plumbing of Erebus volcano, Antarctica, by open-path FTIR spectroscopy of gas emissions, J. Volcanol. Geoth. Res., 177, Volcanology of Erebus volcano, Antarctica, 743-754, ISSN 0377 0273, doi:10.1016/j.jvolgeores.2007.08.022, 2008.

Oppenheimer, C., Tsanev, V. I., Braban, C. F., Cox, R. A., Adams, J. W., Aiuppa, A., Bobrowski, N., Delmelle, P., Barclay, J., and McGonigle, A. J. S.: BrO formation in volcanic plumes, Geochim. Cosmochim. Ac., 70, 2935-2941, 2006.

Pennisi, M. and Le Cloarec, M.: Variations of Cl, F, and S in Mount Etna's plume, Italy, between 1992 and 1995, J. Geophys. Res., 103, 5061-5066, 1998.

Perner, D., Ehalt, D. H., Pätz, H. W., Platt, U., Röth, E. P., and Volz, A.: $\mathrm{OH}$ radicals in the lower troposphere, Geophys. Res. Lett. 3, 466-468, 1976.

Roberts, T. J., Braban, C. F., Martin, R. S., Oppenheimer, C. Adams, J. W., Cox, T. Jones, R. L., and Griffiths, P. T.: Modeling reactive halogen formation and ozone depletion in volcanic plumes, Chem. Geol. 263, 151-163, 2009.

Salerno, G. G., Burton, M. R., Oppenheimer, C., Caltabiano, T., Randazzo, D., Bruno, N., and Longo, V.: Three-years of $\mathrm{SO}_{2}$ flux measurements of Mt. Etna using an automated UV scanner array: Comparison with conventional traverses and uncertainties in flux retrieval, J. Volcanol. Geoth. Res., 183, 76-83, 2009.

Shinohara, H.: A missing link between volcanic degassing and chloride partitioning experiments, Chem. Geol., 263, 51-59, 2009.

Spilliaert, N., Metrich, N., and Allard, P.: S-Cl-F degassing pattern of water rich alkali basalt: modelling and relationship with eruption styles of Mount Etna volcano, Earth Planet. Sci. Lett., 248, 772-786, 2006. 
Stoiber, R. E. and Rose, W. I.: The geochemistry of Central American volcanic gas condensates, Geol. Soc. Am. Bull., 81, 28912911, 1970.

Stutz, J. and Platt, U.: Numerical analysis and estimation of the statistical error of differential optical absorption spectroscopy measurements with least-squares methods, Appl. Optics, 35, 60416053, doi:10.1364/AO.35.006041, 1996.

Tazieff, H. and Sabroux, J. C.: Forecasting Volcanic Events (Developments in Volcanology), Elsevier Science, Ltd., London, Amsterdam, New York, 1983.

Villemant, B. and Boudon, $\mathrm{G}$.: $\mathrm{H}_{2} \mathrm{O}$ and halogen ( $\left.\mathrm{F}, \mathrm{Br}, \mathrm{Cl}\right)$ behaviour during shallow magma degassing process, Earth Planet. Sci. Lett., 168, 271-286, 1999.

Vogel, L., Kern, C., Bobrowski, N., Hörmann C., von Glasow, R., and Platt, U.: Observation of halogen oxides in volcanic plumes at Different Plume Ages, EGU, Vienna, 2010.
Vogel, L., Bobrowski, N., Fickel, M., Hörmann C., Kern, C., von Glasow, R., and Platt, U.: Volcanic plumes: BrO formation during the first 100 minutes after emission, EGU, Vienna, 2012a.

Vogel, L., Sihler, H., Lampel, J., Wagner, T., and Platt, U.: Retrieval interval mapping, a tool to optimize the spectral retrieval range in differential optical absorption spectroscopy, Atmos. Meas. Tech. Discuss., 5, 4195-4247, doi:10.5194/amtd-5-4195-2012, 2012 b.

von Glasow, R.: Atmospheric chemistry in volcanic plumes, P. Natl. Acad. Sci. USA, 107, 6594-6599, 2010.

von Glasow, R., Bobrowski, N., and Kern, C.: The effects of volcanic eruptions on atmospheric chemistry. Chem. Geol., 263, 131-142, doi:10.1016/j.chemgeo.2008.08.020, 2009.

Wennberg, P.: Bromine explosion, Nature, 397, 299-300, 1999. 